exi:ted, but they have now almost entirely vanished (their temperature having sunk to from $5^{\circ}$ to $7^{\circ} \mathrm{C}$ ). Dyngjufjöll, especially the valley of Askja, are the only localities in these regions, where volcanic manifestations of this character are now to be seen ; and there hot springs, claypits, sulphur-mines, and fumaroles of every kind are well developed. But these appearances are to be connected with an enormous eruption which occurred as late as 1875 Throughout the whole of Odázahraun I have come upon no traces of subterranean heat, except at the places here mentioned. About the peninsula of Reykjanes which I explored last year, many more signs of activity were found, which seems to show that in that locality the volcanic disturb inces are to be referred to a later period than those of Ódárahraun.

The northern edge of Vatnajökul has never been examined before. In my journey I was enabled to take the various elevations of this glacier, and found that at its western extremi $y$, in the ncighbourhood of Vonarskary, it rises to its greatest height, over 6000 feet. Fast of this point it becomes lower, until it rises again about Kverkfjoll, where an upheaval is perceptible right across it from north to south. From the hollow, or lowest point, the largest glacier in Iceland has taken its course. It is important that this glacier should be carefully examined, but its exploration would require a long time, for it is almost impossible to make a lengthered stay here, on account of the utter barrenness of the region, and the roughness of the weather.

In this journey 1 succeeded in solving the geographical riddle, which of the many rivers of Iceland is the longest. It has hitherto been assumed that Jokulsá in Axarfjörd was the longest, roo English miles; and that next to it came tjórsá, 96 miles long; but I have now ascertained that pjórsa is by far the longest river in Iceland, its course being about I 20 miles, while Jökulsá is only 95. Hitherto, also, it has been supposed that the sources of Jokulsa were situated in the spurs of Kistufell ; they are really twenty miles further to the east, under the western slopes of Kverkfjoll. The sources of Fjórsá are situated in the north-westerly portion of Sprengi andr, to the north-west of Fjóroungsalda. pjórsá, too, carries a greater volume of water than Jökulsá. On a July day the latter carries, midway betwcen its source and its mouth (viz. at Grimsstaðir) 14,500 cubic feet of water per second, but Djórsá at the proportionate point (at Tjórsárholt) carries 17,600 cubic feet in the same space of time.

Akreyri, September 7

TH. THORODDSEN

\section{AMERICAN SUMMER ZOOLOGICAL STATIONS}

$\mathrm{I}$ the United States there has been during the past ten years a great increase in the advantages for the study of zoology. Not only has this increase been manifested in the colleges, but also by the facilities for summer study at the sea-shorc. At present we have on the Atlantic coast five stations where there are facilities for students to carry on investigations. These laboratories are of two kinds-one where only the advanced student is allowed to study, the ollier in which any one manifesting a sufficient interest in Nature may be allowed a chance to work upon the marine animals; these latter are themselves divisible into two classes-one in which regular instruction is given, and the other where the student is supposed to study for himself under the direction of an efficient instructor.

The laboratory at Beaufort, North Carolina, connected with Johns Hopkins University, is intended as a place where students of the University, and somewhat advanced students from other colleges, can spend the summer in advanced work. It has attaincd for itself a reputation equalled by no other laboratory of its character in the country, because of the excellence of its work. Being supported by a regular fund, there are advantages connected with it which one will not find in other laboratories which are dependent upon subscriptions. Some excellent specialists spend their summers at this station, and the character of their work is shown in the bulletins published from the laboratory. Although Beaufort is not remarkably rich in variety of forms, still this is counterbalanced by the abundance of certain very interesting animals, for the study of which no better place than Beaufort can be found. As the Gulf Stream strikes on this coast, there are many interesting embryos found in the water. The building is a two-storicd house made to serve as a laboratory, and it is placed within a few feet of high-water mark. The location is a low sandy shore in a rather warm climate, but this is necessary on that coast where nothing else is found. For collecting purposes a steam-launch and sail-boat are used. It is under the direction of Prof. W. K. Brooks, who has done much towards making it what it now is.

Much further north, at Newport, Rhode Island, is another laboratory of a somewhat different character. It is under the charge of Prof. Alexander Agassiz, who, with a few assistants and some advanced students from Harvard College, carries on his investigations on the seashore. Dr. F. Walter Fewkes and C. O. Whitman study regularly at this laboratory. Because of its private character it should rather be classed with the former private laboratories which investigators were accustomed to establish at some favourite place on the sea-shore than with the general laboratories for students, though a certain limited number are admitted each summer. The advantages for study are limited, and the locality rather poor.

In the southern part of Massachusetts, at a place called Wood's Holl, the chicf marine station of the United States is stationcd. This is the Laboratory of the United States IFish Commission. Since 1871 the Fish Commission has each year been located at some point on the New England coast, investigating principally the specific characters of the marine fauna. Prof. Baird, the Commissioner, has had the direction of the Commission since it was first originated, and with the assistance of such eminent American naturalists as Goode, Bean, Verrill, Smith, and Sanderson Smith, the previously unkown New England fauma has been thoroughly studied, and certain parts of the North Atlantic deep sea carefully studied. For many years all the work has been done by specialists employed by Govermment, in a poorly adapted laboratory; but now a new building is bcing erected for the express purpose of serving as a laboratory, and it will be fitted up with all the modem conveniences for zoological and microscopical study. Being supported by an ample Government fund, it is expected that thcre will be a good library connected with it, and we know that there will be a supply of large aquaria, and that all necessary chemicals will be supplied. In addition to the tables for regular employées, there will be room for a limited number of students from some of the larger collcges, who will thus be offered the finest advantages for zoological study to be found in America. For the use of the laboratory there is a steam-launch, and many small boats, while the two steamers Albatross and Fizh Hawk are constantly bringing in material from the deep sea and surface of the ocean. Wood's Holl is excellently adapted for the purposes of a summer laboratory, both becausc of climate and variety and abundance of animal forms. The work already done from the old laboratory is of world-wide renown.

This ends the list of those laboratories intended solely for advanced students. Of the other class, the Summer Institute at Cottage City, Mass, is an example. This is a summer educational institution covering a wide variety of subjects, and intended for teachers who are willing to 
spend their summers in quiet study. Courses of lectures are given in various subjects, one of which is natural history, and the students can, if they choose, supplement their course by laboratory study. It is exceedingly elementary, and none but begrinners attend.

Of a similar character, but of more importance, was the Sumner School of Natural History at Salem, Mass., under the direction of Prof. E. S. Morse. The principle upon which this school started was wrong. The originators secmed to have the idea that courses of lectures were esscntial to the success of the school. Such lectures, if delivered by men of reputation, were costly, and to meet the expenses of the school a large attendance was necessary. But in America the sciences arc not studied by a sufficient number of people to supply such a school, dealing in a limited branch of science, with enough students to defray the cost of lectures ; and few students can afford to pay large tuition fees. So it was that the Salem School had to depend entirely upon outside aid for its continuance, and this being withdrawn, the school was obliged to break up a few years ago. It is, indeed, unfortunate that it was obliged to do this, because it was filling an important place in American scientific education by originating an interest in teachers of the public schools for this branch of study, and thus raising the standard of scientific teaching in the lower schools. If a regular fund could be placed at the disposal of some body of scientific men for the purpose of giving instruction to teachers in this way, it would be an important thing; but unless such regular support be cstablished, other less expensive means of instruction in natural history for beginners must be looked to.

At Annisquam there is another laboratory, under the direction of Prof. Alpheus Hyatt, which has an entirely different plan for teaching beginners. At this laboratory both beginners and advanced students are allowed to study upon paying a merely nominal sum. No special instruction is given, but there is an instructor, Prof. J. B. Van Vleck, who helps the beginner over hard places in his studies. The student is given some animal to make a study of, and he is advised to examine it critically, dissect it, and makc drawings of the parts, all without the aid of a book; and then, having found out all he can without aid, he is given some book to verify his observations. In this way the student goes through all the important groups of marine invertebrate animals, often learning for the first time that he can really see things for himself without the aid of books. The powers of observation are brought into play, and the first foundation of a successful student of Nature are thus laid. How much practical benefit this method of instruction will have in making original investigators cannot be told at present, because the school has been in operation for such a short time. The amount of knowledge possessed by the students at the end of the summer, compared with that with which they started, is certainly encouraging. That this is the proper method of teaching natural history has been satisfactorily demonstrated to those in charge by the results. Both sexes are admitted, and preference is given to thosc who are going to make use of the facts which they learn, either in teaching or in special investigation. The building is a plain one-story-and-a-half house, situated at the water's edge. It is well lighted and firm, and aquaria on each table are furnished with water from a tank filled by a windmill. For collecting purposes there are common boats, and Prof. Hyatt has a schooner yacht, in which he frequently takes parties from the laboratory upon dredging expeditions. Fifteen was the average number of students last summer, and they came from all parts of the country, being mostly teachers in small colleges and schools, and a few medical students and special investigators. In its inception it was intended for beginners, but advanced students are welcomed and given the best tables. The one unfortunate thing about this laboratory is that it is not established on a firm money basis, depending each year upon a grant of money from the Woman's Educational Society of Boston, which each year, so far, has generously given the funds for its maintenance. Neither the director nor the instructor receive salaries for their work, but furnish their summers free to the cause. For the purpose of making collections there is no better place on the eastern coast of the United States, with the exception, perhaps, of Eastport, Maine. The variety of animals is immense, and their abundance is also great, every condition necessary to an extensive fauna being present.

The last laboratory which we shall notice is the one which has long since passed out of active existence, in fact which died with its founder, the elder Agassiz. It was an immense building of wood on the island of Penikese, in Massachusetts, the outermost of the chain known as the Elizabeth Islands. The location was poorly chosen, for the fauna in the vicinity is poor, and there was no regular communication with the mainland, which was twenty miles distant. At one time during its brief existence it had a very large attendance, beginners particularly being attracted by the name of the eminent director. Lectures were given and laboratory practice was allowed each student. At this school such men as Fewkes, Faxon, Brooks, Whitman, and Alexander Agassiz, who have since become eminent in American science, received some of their first instruction in natural history. The death of Agassiz ended the institution, which if it could have been kept up under his direction would no doubt have equalled if not excelled any similar institution in the world. It is doubtful if even under Agassiz's direction this stupendous school could have been carried on, for we understand that the money basis was very insecure, and certainly the expenses were very heavy, and the tuition charges light.

RALPH S. TARR

\section{ON A NEW METHOD FOR THE TEACHING OF SCIENCE IN PUBLIC ELEMENTARY SCHOOLS ${ }^{1}$}

THE desirability of imparting to children some knowledge of the principles of science is now so generally agreed upon that this paper will be devoted not to the argument that science-teaching is necessary, but to a description of a method by which it may be successfully and thoroughly carried out.

In the "Code" under which the system of Government education is carried on in this country, science is mentioned under two heads :-

(I) As a "class-subject" (optional) which may be taught to any or all of the seven "Standards" under which the children are classed, and

(2) As a "specific subject" (also optional) which may only be taken by the children in Standards V., VI., and VII. The specific subjects named are-

I. Algebra.

2. Euclid and Mensuration.

3. Mechanics.

4. Latin.

5. French.

6. Animal Physiology.

7. Botany.

8. Principl s of Agriculture.

9. Chemistry.

Io. Sound, Light, and Heat.

I1. Magnetism and Electricity.

I2. Domestic Economy (Girls).

Either one or two (but not more than two) of these specific subjects may be taken by a child. The course in each subject is divided into three parts, so that a child must remain at school for three years in order to complete the study of any one subject.

The grants paid are at the rate of is. for a "fair" or $2 s$. for a "good" pass in class-subjects, and 4 s. per pass in the specific subjects.

I By W. Jerome Harrion, F.G.S., Science Demonstrator for the Birmingham School Buard. The greater portion of this article was read as a communication to the International Conference on Education, held at the Health Exhibition in July last, and is here reprinted by permission of the Executive Council. 